\title{
The Phenomenon of State Violence in the Student \\ Community: The Views of Greek University Students
}

\author{
Stefanos Danis \\ University of Western Macedonia, Greece \\ Email: sdanis@yahoo.gr \\ Argyris Kyridis (Corresponding author) \\ Aristotle University of Thessaloniki, Greece \\ Email: akiridis@ nured.auth.gr \\ Christos Zagkos \\ Independent Researcher, Greece
}

Christos Tourtouras

Aristotle University of Thessaloniki

Received: July 12, 2016 Accepted: August 29, 2016 Published: October 10, 2016

doi:10.5296/jsr.v7i2.9730 URL: http://dx.doi.org/10.5296/jsr.v7i2.9730

\begin{abstract}
By its nature, the modern nation - state obtains the monopoly of the legitimate authority and the institutionalized violence. The relations of the authority with its citizens are determined by specific regulations and rules, which are supposed to reflect the "social contract". However, the use of state violence in modern societies is being increased during the periods of economic and political crisis. Thus, in Greece during the years of crisis the use of violence by the state mechanisms is an everyday phenomenon. Our research is analyzing the attitude of Greek university students towards state violence in Greece. Regarding methodology, two methodological tools were used, meeting the requirements of the research: a questionnaire with closed questions, in order to quantitatively investigate the attitudes of students regarding various issues, with a 5/point scale Likert. Moreover, a quantitative content analysis was used,
\end{abstract}


investigating a basically qualitative research material, which was derived from the responses to open-ended questions, concerning the perceptions of the university students towards the topic of state violence.

Keywords: State violence, Students' community, Higher education

\section{Introduction}

Since the end of the $13^{\text {th }}$ century and until the middle of the $4^{\text {th }}$ century, at a time when the modern state is starting to form shape, one can find similar elements of organized communities, containing what characterizes the state nowadays as "organic ensemble of a historical community" (Weil, 1971:171).

The difference between the ancient and the modern state is mainly detected in characteristics, such as the systematic institutionalization of the state power, the high degree of organization and its imposition on a group of people bearing a common national identity, as well as living in a geographical area defined with precision (Braud, 1996: 72-76).

The existence of a modern state requires the concurrence of the following components: a) a designated territory, b) people (or nation / population), c) power imposed in a sovereign way on those residing in it (Dagtoglou, 1986: 62). The separation, therefore, of the national population according to their territory, which is considered to be the distinctive feature of the state, is synthesized by the public authority (the other distinctive feature), which in turn is enhanced to the extent of the sharpening of the various class contradictions within the state, as well as to the extent that the neighboring states become larger, both in extent and in population (Engels, in: Lenin, 2007: 17).

The modern state is making use of a total amount of immediate and indirect institutions. Immediate are those that engage the state authority without imposing a relationship of dependency or allegiance in another institution; whilst indirect are those that are dependent or subordinate to another authoritarian body.

The direct institutions constitute the most vital category, owing to the fact that they contribute to the particular and specific character of the polity and shall not be eliminated without the polity alteration- such as the parliament, the government, the judiciary. Nonetheless, there can be also found various fundamental indirect institutions, such as the police and the military, as well as the mechanisms of surveillance and information (Maurias, 2000:345-346).

\subsection{Violence and the State}

Although the legitimate violence of the state is not directly visible, it makes its every day appearance in many aspects of society. In fact, it is channeled through the "political state", which imposes its will. "The orders are submitted indirectly, cunningly, in order not to cause reactions. It is an invisible power and therefore invulnerable. Sometimes it appears as "public sentiment", sometimes as "imperative of science," as "common sense" of "modernity" and "progress". And the citizen assimilates messages, adopts them, obeys in the 
“well-constructed" commandments» (Fromm, 1971: 190-191)

As stated by Simopoulos (1995): "In the West, the so-called democracies are in fact cruel and immoral, violent oligarchies. Institutions, mechanisms for state function are sometimes determined by the violent system. That and the "priesthood" are to select the form of political power and not the voters, who have the illusion that they elect "people's representatives" and governments, when in fact they merely legitimize violence and fraud with their vote [...] Politicians and bureaucrats impose their own rules. They define themselves what is honest and what is moral. The society is humiliated by professional politicians, while political enterprises manage power as a form of contract work. Corruption with a thousand faces: imposition of political "faces" and leaders, nepotism, cronyism, political corruption, plutocracy, populism, dogmatism, slogans [...] "(p. 13 -14).

The State exercises its power in relation to the power relations in order to achieve domination, coercion, subjugation and an organized form of oppression (Poulantzas, 1985b: 65-66). It constitutes, in essence, 'people's power over people, based within the lawful, ie the allegedly legitimate, violence» (Weber, 1956: 63), whilst it makes a usage of mechanisms for compliance with the rules and seems to finally manages to monopolize successful legal violence, in order to avoid the overthrow, without this, however, automatically implying the legitimacy of any act of violence (Weber, 1987: 506).

Governments, as organized and institutionalized forces, use violence to achieve prescribed goals. Violence, apart from being a means to an end, is the condition in which people begin to think and to do specific acts, in order to achieve this very purpose. The only thing the state requires is the legitimization of the violence that it imposes itself, which finally manages to justify by invoking the importance of a purpose always put upon in the future (Arendt, 2000: 112-113). Of course, we should note that the ability of governments and of their state mechanism to exercise violence and to control their territory depends on factors, such as the level of financial and policy development (Evans, 1995; Besley and Persson, 2011 ).

With the assistance of the state violence, a system, which dominates the social community, is assured, as well as a relationship of domination of people over other people. The state and the society, public or private, now constitute two different worlds. The state obtains the monopoly of the legitimate authority and the institutionalized violence. The relations of the authority with its citizens are determined by specific regulations and rules, which are supposed to reflect the "social contract". As a result, a mechanism of legal violence is created; a repressive, administrative, bureaucratic and ideological one. The monopoly of violence has its foundations on the merit instead of on legality, consisting in most of the cases the resultant of political, financial and military domination (Simopoulos, ibid: 231-233).

The state, when using the violence against the social groups, has various and spectacular features. After all, it is in possession of many methods, in order to use a veiled dimension of violence (Stohl \& Lopez, 1984).

Besides, in a long term, no state power is in a position to be imposed and maintained only with the power of coercion and of similar repressive mechanisms. The raw retention of direct 
coercion and violence creates contrasts, which cannot be solved by these practices (Charalambis, 1985: 264). Hence, a number of other coercive measures compose the "arsenal" of a system with the purpose of the manipulation of the broad popular masses. A few of these are described below.

\subsection{Mechanisms of the Exercise of the State Violence}

The devaluation of the rule of law legitimizes institutionalizations that lead to the exceptional power of repressive mechanisms. These mechanisms alter the fair state character of the social system and strengthen the state violence and the arbitrariness. The gradual concessions eventually result to the mutation of the rule of law to a totalitarian state (Mill, 1983: 101).

In addition, the high percentage of the corruption of the police itself and the reluctance of the state to intervene radically allow the frequent diversion of the state practices, in events of overt and violent exercise of power, rather than in policies of administration and service of the public interest (Pihas, 1997: 551).Among the various manifestations of the public corruption of authority, here are corruption and bribe, abuse and embezzlement, fraud, extortion, nepotism. The "background" of it all is the state power, meaning the way that the state performs its functions (Mill, ibid: 148).

Even culture is employed for the stupefaction of the citizens. Culture no longer seeks for the spiritual and aesthetic culture and information, but aims to the superficial, shallow knowledge and the stultifying entertainment. In fact, in the framework of the globalization of the economy, the system proceeds to the control of the common thinking, through online networking centers, which are developed into ideological enforcement protagonists (Simopoulos, ibid: 17-18). The social control is sought through various techniques, such as, for example, the distraction of the public attention from the actual social problems, by barraging instead insignificant information, with the assistance of the public media. Also, there occurs the gradual implementation of unpopular measures, which otherwise, if applied directly, would lead to extreme social conflicts (Stergioulis, 1996: 668). Furthermore, the strategy of "the use of emotion rather than logic," prevents logical analysis and critical thinking among the citizens, making them easier to be manipulated. In addition, the strategy of "creating problems and offering solutions" creates the desired conditions that could cause foreseeable reactions from the world, leading to "commonly acceptable" measures. Thus, in the case of the "outbreak" of crime, the requirement for larger policing of the masses is created, actually against their own freedoms (Curran, 2001: 56).

Therefore, the media shape and reproduce each time a specific perception of reality, creating false consciousness. They provide the citizen with a partial view of reality, removing any possibility of generalization and search of meaningful correlations among the situations (Bryant \& Oliver, 2009; Stergioulis, ibid : 672). At the same time, the social media play their instrumental role towards the organization and spread of protest (Kulish, 2011; Zuquete, 2011).

The administration of the concept of terrorism, of course, has a dominant position in the network of the repressive mechanisms of the state. It regards a social devising and a political 
choice, under which the state makes the effort to eliminate any possible resistances, as well as to ensure social partnerships, with a view to enhance its authority and to subordinate everyone under its power (Manitakis \& Takis, 2004: 26).

In Greece, despite the plethora of mechanisms, the protection of the human rights of citizens is not ensured. On the contrary, the human rights are quite often circumvented and restricted by government agencies, in the guise of protecting the state. The accelerated technological progress constitutes nowadays a new form of social control, which is inconsistent with the constitutional guarantee of individual rights. The information collected for the entire population are increased, in order to facilitate the monitoring and manipulation of human beings (see for example the installation of closed circuit surveillance cameras). Social control is generally a function inherent in maintaining social cohesion (Tsiris, 2002: 61, 93).

The collection of personal information in electronic databases, the information system «Schengen», police and judicial cooperation at European and international level, the monitoring of telephone conferences with advanced technological systems and the "electronic surveillance at home," are all forms of contemporary social control, which under the guise of ensuring and maintaining internal security and public order severely restrict the civil liberties of the citizens. The Privacy right is repealed to a large extends and tends to be replaced by the dogma of the absolute transparency, circumventing any notion of privacy and confidentiality (Haidou, 2003: 99).

\section{Research Methodology}

The short avocation with the issue of this research, both in Greece and internationally, gives to this paper the requisite scientific originality. Two methodological tools were used, meeting the requirements of the research: a questionnaire with closed questions, in order to quantitatively investigate the attitudes of students regarding various issues, with a 5/point scale Likert (see. on Michalopoulou, 1992; Kyriazis, 2001). Moreover, a quantitative content analysis was used, investigating a basically qualitative research material, which was derived from the responses to open-ended questions, concerning the perceptions of the subjects towards the topic of state violence ("What is your opinion about state violence?"). The "topic" was regarded to be the recording unit, as it was thought to be more convenient for the purposes of this investigation to illustrate the attitudes, perceptions and beliefs of students. From the replies of the 172 research subjects, 328 statements were derived, that were included in five thematic categories and related subcategories.

Regarding the method of the standardized questionnaire, it generally enables data collection from a large number of people on the same issues. Hence, comparability, the possibility of quantification and the statistical analysis renders it as one of the main tools of quantitative research. The correlation of variables, which is the standard model of analysis for determining empirical trends and uniformity, is a large overlap with the standardized questionnaire, in an effort to demonstrate empirical generalizations, the emphasis on objectivity and the extraction of valid results (Kyriazi, ibid: 119 -120).

The questions were grouped (see the aggregated annex table), in order to facilitate statistical 
analysis, depending on their content, to those related to demographics of the sample, those referring to the views of respondents on the authoritative bodies of state violence, the ways of exercising state violence, the necessity of exercise of state violence and its legitimacy.

After collecting the questionnaires, the extraction of thematic categories and subcategories, their encoding, the quantification of the data and their admission in the statistical analysis program SPSS were followed (Hancock, 2010). The reliability of the survey questionnaire was proved to be strong, since the reliability coefficient (Cronbach's a) was found statistically significant and equal to 0.804 .

The survey was conducted during the period of December 2010-June 2011. The research sample consisted of 172 undergraduate students in total (64 boys and 108 girls), from whom 111 were undergraduates and 61 postgraduates from various university institutions in the country (132 attended university and 40 at ATEI). Specifically, 17.4\% of the sample had studied humanities, $40.1 \%$ teaching, $31.4 \%$ were enrolled in science and $11.1 \%$ in social sciences.

\section{Results of the research}

\subsection{Quantitative Analysis}

\subsubsection{Description}

In the total number of the 172 students that participated in our survey, as far as political ideology is concerned, 1.4\% identified themselves as far right, $16.7 \%$ in the right, $27.5 \%$ in the centrist space, $42.1 \%$ in the left and $12.3 \%$ in the far left and anarchist space. It is worth mentioning that the $19.8 \%$ of the students did not answer this question, either avoiding exposing their ideological integration or declaring in this way their distance from the wider political area. After all, in a relative question, the $56.4 \%$ reported themselves as little or no politicized or completely indifferent to the political situation.

Furthermore, in a similar question, the vast majority of the sample indicated that they did not participate in any partisan organization $(87.1 \%)$ or labor union $(86 \%)$ and their political preferences were, in their majority, stable (64\%). Similar results were also exported as far as their parents are concerned. Finally, the majority of the student sample always votes in national elections $(67.4 \%)$, in the European elections $(51.2 \%)$ and in the local government elections (54.6\%). Conversely, they indicate to have never voted in the elections of associations (by 49.4\%), whilst they have sometimes voted in the student elections (by $38.4 \%$ ). Fathers seemed to have an analogous fluctuation, but much more enhanced, demonstrating a stronger politicization compared to their children. The responses, which were derived from the majority of the sample regarding mothers, are shown to be similar.

In addition, we wanted to investigate to what extent the respondents agree or disagree with the 30 questions / statements of the questionnaire. Thus, while there is no significant divergence between those who agree and those who disagree with the view that "state violence is the violence exercised by the police" (about $32 \%$ on each side), the first respondents, however, seem to obviously outweigh in the question whether "the state 
violence is contained in the outbreak of violence by the police" (54\% versus about $21 \%$, respectively). Also, far greater is the percentage of dissidents to the position that "the state violence is included in the symbolic violence" (68\% compared to only $15.5 \%$ of those who agree), while $75 \%$ agree with the statement that "government violence is the provocative actions of the political parties and the deputies". The rates are shared almost equally between the dissidents and those who are in favor of the positions "state violence is the preventive, undue police control on the road", "State violence can be exercised through the terror of law" and "the army is a body of the state violence". There is a significant outweigh of dissidents with the positions: "the State is entitled to exercise violence", "without the state violence the structure of the state is under threat", "state violence is the continuous evaluation and monitoring of the performance of students through examinations", "... is lawful ", "... is a prerequisite in defense and in legitimacy of the state", "...it is necessary to maintain the cohesion of the social fabric", "...is essential but excessive", "...a necessary "evil", since through this, the constitutional, political and economic structure of a country is protected" and "via the state violence social peace is imposed". On the contrary, respondents agree on significantly higher rates with the following statements: "State violence is constantly seen in atrocious working conditions, accommodation and living conditions of migrants and in the mass deportations," "state violence is the continued increase in taxes and VAT", "... promoted through the system of cameras and surveillance of privacy", "... is the constant alteration of labor relations", "... the threat of the bankruptcy of the state", "...censorship in the media and on the internet", "...political mobilization against the strikers", "State violence is reinforced by the lack of the rule of law", "...is the institutional fortification of the economic, military and political elite ", "...based on the concepts of "national interest" and "legitimacy", "...is changing and varies from country to country," "the configuration of the public consciousness through television is state violence" and "state violence is violence by the state to its citizens". Finally, regarding the position "the state violence is being promoted by the privatization of education", there is a disagreement of approximately $34 \%$, while $43 \%$ did not take a clear position.

\subsubsection{Correlations between the variables}

\subsubsection{Differentiations regarding the gender}

The female students agree on significantly greater rate than their male peers $(75.7 \%$ vs. $71.9 \%$ respectively) with the statement that "state violence is violence wielded by the State to citizens" $\left[\mathrm{x}^{2}(1)=6.745, \mathrm{p}<0.05\right]$. The female students were presented to be with statistic significance more subversive than the male students about whether "the state violence is legitimate" $\left[\mathrm{x}^{2}(1)=6.861, \mathrm{p}=0.048<0.05\right]$. They disagree, therefore, with the specific statement at a rate of $70.5 \%$, as opposed to their male colleagues who disagree at the rate of $56.2 \%$.

Students also agree significantly more than their fellow student (17.4\% vs. $13.1 \%$ respectively) with the statement that "the state violence is ever seen in atrocious working conditions, accommodation and living conditions of immigrants and their mass expulsions" $\left[\mathrm{x}^{2}(1)=7.450, \mathrm{p}=0.011<0.05\right]$. 


\subsubsection{Differentiations regarding the father's occupation}

The majority of children whose fathers are professionals/scientists $(88.3 \%)$, clerical $(76.5 \%)$ and farmers $(78.2 \%)$ disagree with the position that "without state violence the structure of the state is in danger" at a statistically significant level $\left[\mathrm{x}^{2}(6)=26.408, \mathrm{p}=0.003<0.05\right]$, compared to those whose fathers are workers $(31.3 \%)$, technicians $(57.1 \%)$, civil servants $(65.5 \%)$ and traders $(63.5 \%)$.

Likewise, male and female students with fathers who are occupied as merchants $(27.3 \%)$, laborers (49.9\%) and technicians (14.3\%), agree significantly more than others with a similar statement that "state violence is a precondition for the advocacy and legitimacy of the state" $\left[\mathrm{x}^{2}(6)=30.850, \mathrm{p}=0.0005<0.05\right]$. They even disagree with the opinion that "the state violence is necessary but excessive", in $89.4 \%$ of children with fathers scientists, $72.3 \%$ of those with fathers as civil servants and $69.6 \%$ of children with fathers as farmers. Instead, significantly lower percentages of oppositions are expressed $\left[\mathrm{x}^{2}(6)=18.078, \mathrm{p}=0.044<0.05\right]$ by children whose fathers are once again workers, artisans and traders $(50 \%, 59.3 \%$ and $36.4 \%$, respectively )

Also, with the statement: "State violence is a necessary evil, because through this the constitutional, political and economic structure of a country is protected" there is a statistically significantly less rate of agreement $\left[\mathrm{x}^{2}(6)=17.677, \mathrm{p}=0.048<0.05\right]$ among female and male students whose fathers are scientists, civil servants and farmers $(15.8 \%, 12 \%$ and $4.3 \%$, respectively), as opposed to those with fathers who work as clerical workers, craftsmen, merchants and laborers $(29.4 \%, 35,8 \%, 27.3 \%$ and $25 \%$, respectively).

With the statement: "the state violence imposes the social peace" only $5.3 \%$ of children with a scientist father agree, $17.3 \%$ of those with a father as civil servant, $11.8 \%$ as a private employee, $9.1 \%$ with a merchant father, and there is no student with a farmer father to consent to the terms above. In contrast, the agreement rates are significantly higher amongst children agreement whose fathers are craftsmen (21.4\%) and worker (31.2\%). The correlation between those two variables ("father's occupation" and "degree of agreement or disagreement with the statement above") is statistically significant $\left[x^{2}(6)=20.459, p=0.011<0.05\right]$.

As to whether the "state violence is based on the concepts of "national interest" and "legitimacy", only male and female students with fathers occupied as merchants and workers seem to agree on high percentages $(72.7 \%$ and $81.3 \%$, respectively ), as opposed to the children of other occupational categories, which are consistent in a statistically significantly lower rate, about $40 \%$ on average $\left[\mathrm{x}^{2}(6)=23.555, \mathrm{p}=0.016<0.05\right]$.

We identify, therefore, a steadily conservative attitude towards various issues regarding the state violence of those children who come from families, where the headed fathers are merchants and laborers.

\subsubsection{Variations regarding the educational level of the family}

With the statement "state violence is the violence exercised by the police" higher percentages of female and male students whose parents are graduates of higher education agree (on 
average $45 \%$ and $38 \%$ respectively), as opposed to less educated families. The correlation is statistically significant $\left[\mathrm{x}^{2}(5)=22.391, \mathrm{p}<0.05\right.$ compared to the father's education and $\mathrm{x}^{2}(5)=16.988, \mathrm{p}<0.05$ compared with the mother's education]. Similar results occur in case the above statement is changed as: "State violence is inherent in the violence exercised by the police". In this case however, an even greater consensus among children with less educated parents is observed.

Regarding whether "state violence is the preventive, undue police control on the road", children with higher educated parents express a higher agreement in higher rates (on average $54 \%$ and $48 \%$ respectively), as opposed to those with less educated parents $\left[x^{2}(5)=26.749\right.$, $\mathrm{p}<0.05$ correlated with the father's education and $\mathrm{x}^{2}(5)=21.948, \mathrm{p}<0.05$ correlated with the mother's education]. Nonetheless, what causes surprise is the finding that all students, whose parents are postgraduate diploma holders, avoid to express themselves for or against the above statement.

The statement "the state violence is necessary but excessive" finds less agreement among male and female students, whose fathers are university graduates and in a possession of a postgraduate degree $(16.6 \%, 5.2 \%$ and $0 \%$ respectively). The correlation is statistically significant $\left[\mathrm{x}^{2}(5)=16.094, \mathrm{p}<0.05\right]$.

Regarding the statement "state violence is a necessary evil, because via this the constitutional, political and economic structure of a country is protected", there is an often higher rate of disagreement among children whose fathers have graduated from higher education $(73.6 \%)$. The correlation demonstrated is statistically significant $\left[\mathrm{x}^{2}(5)=16.1, \mathrm{p}<0.05\right]$.

The vast majority of students, regardless of their father's educational level, agree with that "state violence is the political mobilization against the strikers". However, even larger percentages are indicated by those whose fathers are graduates from tertiary education $(83.8 \%)$ or have graduated from primary school $(85.7 \%)$, turning the relationship between the variables to a statistically significant one $\left[\mathrm{x}^{2}(5)=16.277, \mathrm{p}<0.05\right]$.

Finally, the statement "state violence is based on the concepts of "national interest" and "legality"", there occurs a higher rate of agreement as expressed by students and graduate students, whose fathers are graduates of primary school or completely illiterate $36.7 \%$ and $75 \%$ respectively). The rest of the students are expressing disagreement rates of around $25 \%$. The correlation is statistically significant $\left[\mathrm{x}^{2}(5)=18.282, \mathrm{p}<0.05\right]$.

\subsubsection{Variations of male and female students regarding their level of education and age}

With the statement "state violence is inherent in the imposition of violence by the police" $73.8 \%$ of postgraduate students agree, as opposed to far fewer undergraduates (43.2\%). In other words, the level of education of the students play a statistically significant role in shaping their attitudes regarding the above position $\left[\mathrm{x}^{2}(1)=14.105, \mathrm{p}<0.05\right]$, as well as in the statement "state violence is included in the symbolic violence". As regards the last one, we also observe $74.3 \%$ of postgraduate students to come in agreement, as well as over $51 \%$ of their undergraduate colleagues $\left[\mathrm{x}^{2}(1)=8.069, \mathrm{p}<0.05\right]$. 
Similarly, $63.3 \%$ of postgraduate male and female students reckon that "state violence is the constant alteration of labor relations", unlike their undergraduate colleagues, who agree only in a percentage of $50 \%\left[\mathrm{x}^{2}(1)=5.526, \mathrm{p}<0.05\right]$. Instead, the position "state violence is necessary, but excessive" finds an agreement among only $6.5 \%$ of postgraduates, as opposed to the much larger proportion of undergraduates $(23,7 \%)\left[\mathrm{x}^{2}(1)=9.886, \mathrm{p}<0.05\right]$.

Also, $67.2 \%$ of postgraduates disagree with the view that "the state violence is a necessary evil, because through this the constitutional, political and economic structure of a country is protected", unlike undergraduates, who seem to disagree at a considerably smaller proportion $(55 \%)\left[\mathrm{x}^{2}(1)=5.707, \mathrm{p}<0.05\right]$.

As to whether "the army is an authoritarian body of state violence", $49.2 \%$ of postgraduate students answered affirmatively, compared to $31.8 \%$ of their undergraduate colleagues $\left[\mathrm{x}^{2}(1)=11.389, \mathrm{p}<0.05\right]$. Finally, $81.7 \%$ of postgraduates agree with the position that "the state violence is the institutional fortification of the financial, military and political elite", while undergraduate male and female students agree on a percentage of $63,3 \% \quad\left[x^{2}(1)=6.620\right.$, $\mathrm{p}<0.05]$.

It should be finally noted that the undergraduate students of older ages ( 23 years old) answer affirmatively at significantly higher rates than their younger counterparts (18-22 years), when it comes to same and similar to the abovementioned positions. Thus, older students agree more with the statements: "State violence is inherent in symbolic violence", "State violence is the preventive, undue police control on the road", "State violence is the violence exercised by the state, imposed on citizens", "State violence is the constant change of labor relations", "State violence is the threat of bankruptcy of the State", "The army is an exercising element of the state violence", "State violence is the political mobilization against the strikers", "The state violence is reinforced by the lack of rule of law", "State violence is the institutional fortification of the economic, military and political elite", while they disagreed in significantly higher rates than their younger counterparts, when it comes to the more conservative position that "State violence is necessary, but excessive".

\subsubsection{Variations regarding the students' area of residence}

What is generally observed, is the fact that male and female students, who live in Athens and in Thessaloniki, agree in statistically significant higher rates among the others, when it comes to the statements: "The state violence is the violence imposed by the police" $\left[\mathrm{x}^{2}(3)=11.457\right.$, $\mathrm{p}<0.05]$, "The state violence is the preventive, undue police control on the road" $\left[\mathrm{x}^{2}(3)=14.802, \mathrm{p}<0.05\right]$ and "State violence is the censorship in the media and in the internet" $\left[\mathrm{x}^{2}(3)=13.66, \mathrm{p}<0.05\right]$.

On the contrary, residents in Athens and Thessaloniki disagree in statistically significantly higher rates than the rest, with regard to the conservative positions: "State violence is a prerequisite in the defense and legitimacy of the state" $\left[\mathrm{x}^{2}(3)=14.259, \mathrm{p}<0.05\right]$, "State violence is necessary but excessive" $\left[\mathrm{x}^{2}(3)=16.543, \mathrm{p}<0.05\right]$. Regarding these two statements, residents in towns also disagree in similar rates. 


\subsubsection{Differentiations of the students regarding their political position}

Students that identify themselves as left-winged, far left-winged and anarchists, seem to differ in their entirety, in statistically significant levels, in comparison with those that belongs in the far right-wing, right-wing and centrist political space, as far as the various positions discussed in this paper is concerned. Hence, the first agree on significantly higher rates with the views: "state violence is inherent in causing violence by the police" $\left[\mathrm{x}^{2}(5)=19.374\right.$, $\mathrm{p}<0.05]$, "the state violence is included in symbolic violence" $\left[\mathrm{x}^{2}(5)=10.714, \mathrm{p}<0.05\right]$, "the formation of consciousness through television is state violence" $\left[\mathrm{x}^{2}(5)=16.349, \mathrm{p}<0.05\right]$ (with this statement students of the central political space agree in similar proportions as well), "state violence is violence imposed by the state to its citizens" $\left[x^{2}(5)=12.706, p<0.05\right]$, "the state violence is promoted by the privatization of education" $\left[\mathrm{x}^{2}(5)=2.848, \mathrm{p}<0.05\right]$, "state violence is promoted through the system of cameras and surveillance privacy" $\left[\mathrm{x}^{2}(5)=13.443\right.$, $\mathrm{p}<0.05$ ] (the centrists students approach once again their colleagues percentages of the left-wing and anarchist space), "state violence is the political mobilization against strikers" $\left[\mathrm{x}^{2}(5)=20.801, \mathrm{p}<0.05\right]$, "The state violence is reinforced by the lack of the rule of law" $\left[\mathrm{x}^{2}(5)=18.517, \mathrm{p}<0.05\right]$ (the centrists again converge with their colleagues of the left-wing and anarchist space) and "State violence is ever seen in atrocious working conditions, accommodation and living conditions of migrants and in the mass deportations" $\left[\mathrm{x}^{2}(5)=16.655, \mathrm{p}<0.05\right]$. On the contrary, male and female students of the left-wing, extreme left-wing and anarchist political space disagree on statistically significantly higher rates compared to their colleagues of the conservative center-right-wing political space, regarding the statements: "The State is entitled to exercise violence" $\left[\mathrm{x}^{2}(5)=43.561, \mathrm{p}<0.05\right]$, "without state violence, the structure of the state is under threat" $\left[\mathrm{x}^{2}(5)=19.419, \mathrm{p}<0.05\right]$, "the state violence is essential to maintain the coherence of social fabric" $\left[x^{2}(5)=16.263, p<0.05\right]$ (the centrists students disagree with this position in similar proportions with their left-wing counterparts), "state violence is necessary but excessive" $\left[\mathrm{x}^{2}(5)=39.968, \mathrm{p}<0.05\right]$ and "state violence is a necessary evil, because through this the constitutional, political and economic structure of a country is protected" $\left[\mathrm{x}^{2}(5)=20.801, \mathrm{p}<0.05\right]$.

\subsection{Qualitative Analysis}

From the same content analysis to the open question included in the questionnaire (see above "research methodology"), 328 reports were resulted, of which $36.9 \%$ were derived from male and female students with father and $19.8 \%$ with mother, which were occupied as civil servants, whilst the $41.7 \%$ had a mother devoted to household. Nonetheless, much smaller percentages were attributable to other professional categories. Also, 36.9\% of the reports corresponded to students with father graduates from AEI / TEI and 32.7\% elementary graduated fathers. Similarly, regarding the mother's education, students with mothers that were graduated from elementary or secondary education responded at a rate of $28.7 \%$ and $38.3 \%$ respectively, while those with a mother that has graduated from higher education responded at the rate of $26.6 \%$ cumulatively. Still, the vast majority of references $(80.8 \%)$ derived from university students, instead from ATEI, and, indeed, from undergraduates $(62.8 \%)$ than postgraduate students, aged $18-22$ years $(54.9 \%)$, from whom the majority lived in urban centers $(78.1 \%)$ and belonged to the center-left wing political space $(72.9 \%)$. 
Moreover, the vast majority of references related to the open-ended question are derived from students who did not belong to any political organization or partisan union body, neither did their parents, while at the same time, they stated that they and their parents have stable political preferences, which are expressed with their constant participation in various types of electoral processes (national elections, Euro elections, elections in the OTA), but not always in the elections of the professional and student associations.

Here below, we present in detail the topics that emerged from the content analysis we have conducted, as well as characteristic excerpts of the references that constituted each of the topics and their subcategories.

\subsubsection{Thematic categories}

\subsubsection{Authoritarian bodies of the state violence}

The first thematic category regards the state violence institutions, representing the $15.2 \%$ of total reports. In this category, the following six distinct subcategories are being observed: "Police", "army", "parliament", "Media", "dominant class" and "others in authority".

The references that were recorded in relation to the police and the media, as the state violence bodies, were in each case $3.7 \%$ of the references: "excessive and unnecessary physical force caused by the police (...)the communicative violence imposed by the media with news that are directed".

The army as a body of state violence gathered 5 references $(1.5 \%)$, as: "(...) violence carried out by the army of citizens (...)".

The Parliament House as a state violence body was presented in texts gathering 8 references (2.4\%): "(...) violence caused by MPs and ministers".

The subcategory relevant to the ruling class attracted just 3 references $(0.9 \%)$ : "(...) the way the powerful state manipulates its citizens".

Finally, others in authority, as authoritarian bodies of state violence, received 10 references (3\%): "(...) State violence is exercised by the legitimate institutions of the state".

\subsubsection{Methods of imposing state violence}

The second thematic category concerns the topic of State violence methods with 225 references and the percentage reaching the $68.6 \%$ of total reports. The subcategories of this thematic is "laws / measures", "politics", "violence", "imposition", "violation of rights", "abuse", "psychological methods" (pressure, insecurity, intimidation, manipulation and exploitation), "economy" (labor, tax, wages, bankruptcy and loans) and finally "'lack of education, justice, quality of life/well-being and freedom". References recorded in the texts of the students and were related to the laws/measures as State violence methods constituted 7\% of all reports in that category: "(...)to impose measures without the approval of the citizens". Reports about politics as a state violence method, were $3 \%$ "(...) the plundering of national resources and revenues from political and state bodies". 
In a $8.5 \%$ (28 reports), violence is presented as a method of exercise of the state violence: "(...) violence is exercised by the State directly or indirectly". References related to enforcement of violence were 24 (7.3\%): "(...) censorship imposition" (...) imposition of the views and positions of the ruling political party".

Those related to the rights violation were 16 (4.9\%): "(..)the violation of basic civil liberties / (...)recording of personal data / (...)cameras on the streets / (...)supervision of our privacy".

In the $2.1 \%$ of the references ( 7 references), abuse of authority is appeared as a method of exercise of the state violence: "(...)any form of exercise of power on the citizen / (...)the promiscuity of the state apparatus / (...)government intervention to an extreme and unfair degree". The largest number of references of this thematic category is gathered in the subcategory associated with the psychological state of the violence methods (45 reports, at a rate of $13.8 \%)$. Among these, 11 refer to the pressure: "(...) the imposition of conscious pressure of the state apparatus". Just 3 are related to insecurity: "(...) the insecurity felt by citizens due to the antisocial actions of the state". The 14 references regard the phenomenon of bullying: "(...) creation of phobic syndromes (terrorism, bankruptcy, war) / (...) via methods of terrorism and repression". The 13 references are listed under the notion of manipulation: "(...)the methodical (through the media) manipulation of citizens / (...)the withdrawal from the bulk of the citizens of their purity of political thinking and judgment". Finally, four references concern the exploitation: "(...) the exploitation of human resources".

In a rate of $11.6 \%$ (38 references), the economy is presented as a method of exercise of the state violence. Of these, 11 are related to work: "(...)an increase in unemployment / (...)redundancies". The 12 are reported regarding taxes "(...)through taxation of citizens / (...)Price increases (fuel, food, bills, utilities)". The 7 are related to salaries: "(...)wage reduction(...)pensions". The 5 refer to bankruptcy: "(...)the constant threat of bankruptcy of the state". The remaining 3 refer to loans: "(...)IMF and ECB / (...)the continuous borrowing from banks".

Finally, references related to the lack of state violence as an exercise method were $34(10.4 \%$ rate). Among these, five concerned the lack of education: "(...)the attempt of the state to so that people remain uneducated". The 11 are about the lack of justice: "(...)the absence of the rule of law / (...)there is no democracy". The 7 referred to the lack of quality of life and prosperity: "(...)the loss of quality of life". The remaining 10 were concerning the lack of freedom: "(...)the direct or indirect undermining of personal, social, civic political freedom".

\subsubsection{Characteristics of the state violence}

References recorded on the thematic category of the characteristics of state violence were 24 (7.7\% of total reports). The subcategory of this theme is the "necessity", the "legitimacy" and "timelessness".

The first subcategory is represented with 10 reports $(3.1 \%)$, as: "(...)State violence is necessary to ensure public safety / (...)an ultimate necessary evil".

The second occurs with 11 reports $(3.4 \%)$ : "(..)State violence is applied on the occasion of 
events and situations that could potentially threaten the "legality" ".

The last subcategory appears only with 3 references in the texts of students $(0.9 \%)$ : "(...)all the methods used over time by the state(...)have over the centuries similarities and differences".

\subsubsection{Objectives of the state violence}

The fourth thematic category concerns the targets of the exercise of state, with 21 references and $6.4 \%$. The subcategory of this thematic is "interests" and "power".

References related to the interests served by the exercise of state violence were 16 (4.9\%): "(...)aimed to promote lawlessness and selfish goals of a few people against the interests of the citizens / (...)the state serves the interests of the social class that structures the political-economic system".

Finally, at a rate of $1.5 \%$ (5 reviews), the maintenance of the power is displayed as a purpose of the violence that is imposed by the state: "(...)the continuous effort of the state to retain power / (...)aims to maintain the ruling class".

\subsubsection{Ethical dimensions of state violence}

The last subject category is divided into various subcategories and relates to the ethical dimensions of state violence, with 8 reports and 2.4\%: "(...)the humiliation of the citizen, through the circumvention of the values, history, culture, beliefs of the person, as well as the total intellectual necrosis".

\section{Instead of an Epilogue}

Pauwels \& De Waele (2014: 137) correctly pointed out that "Our integrative explanatory model of political violence is based on the assumption that perceived strains and weak social integration may affect personal beliefs about the justification of the use of violence". And from this point of view, attitudes and perceptions of students expressed in the survey depict that in Greece in the era of crisis, the state violence continues to constitute the main weapon of political power, in order to impose its will and suppress the reactions of demonstrators protesting against government policies. In this way, the position of Pauwels \& De Waele on the role of weak social integration in the process of the legitimization of violence functions by the exact reverse logic. The destroyed social cohesion as a result of the spread of social vulnerability (Kyridis, 2014: 52-56), leaves considerable room to state violence to conquer and become more brutal, especially on a psychological level. Thus, the state violence acquires an instrumental capacity, that of the regulation, in case, on the contrary, the attitudes of the citizens are considered to be a priori a form of deregulation. Simultaneously, the state violence is aimed to "break" the social ties (social bonds), whose existence has emerged as a key factor in reducing violence (Boehnke et al. 1998; Heitmeyer \& Anhut, 2008). This creates a contradiction in terms, since, on the one hand, the reduced social cohesion has emerged as a significant factor in the exercise of state violence, and while on the other hand, the exercise of the state violence is designed by nature to impair the social cohesion through the fear and the fist. Besides, the more effective the government violence, 
the more loose is the cohesion of social groups (Goode, 1972: 516; Coser, 1956).

The responses of subjects, both in scale and in the open question, seem consistent with the position that the violent repression leads to a clear restriction of demonstrations (Gurr, 1976: 131). It is important, however, to note that the subjects recognize as state violence the symbolic violence by state and by non-state mechanisms, a violence that has as its clearest view to prevent rather than to repress. However, most of the time, the symbolic coercion, instead of preventing, "enrages" the social body and this has the adverse effects (Gurr, 1970).

Also, the responses of the subjects followed the views and the typology of Leites \& Wolf (1970: 156) on the legitimacy of state violence and the state's ability to monopolize violence in the name of law and order.

Particularly interesting are the results that show agreements in the attitudes of people belonging to different social classes or different social groups and, in any event, people appearing at first sight not to belong to the same levels of social stratification. Obviously, such results reveal the distorted expansion of the modern social stratification, which is based on similar wayward class consciousnesses that transcend the limits of Marx's analysis and is extended to the symbolic representations of an individually structured social reality. Apparently, no longer do we refer to class identities, but to individual attributed social positions, related to each other by a bidirectional relationship, which, on the one hand, is established through education and training and, on the other hand, through the relations with the means of production. The class identity can be seen as the network of the ways in which societies perceive themselves in relation to others, the way in which they see the past and the future and of course their relationship to the means of production (Peirce, 1995). According to Munoz (1995: 46), the study of social/class identity refers directly to the study of the history of identity -the way we ourselves describe our identity; the way we talk about ourselves, about others and about our position in society (see also: Poulantzas, 1975).

We could claim that the theories on social stratification nowadays are not particularly developed in the context of a solid scientific debate. It is worth to mention, however, the recent theories of Wright $(1978,1985)$ and Parkin (1971). Wright distinguishes three dimensions of the control of economic resources in the contemporary capitalist production: the control of investment, control of facilities (land, factories, offices, etc.) and control of labor power. The members of the capitalist class exercise control in all the three dimensions of production. The workers in any of them is of great interest is the concept of the contradictory class positions, which is a central point of the theory of Wright. According to this, there are some workers who, whereas they cannot control the production, are able to influence them. Typical examples are the workers of "white collar". Parkin is clearly more influenced by the theory of M. Weber and less by K. Marx. He perceives property as a form of social entrenchment, which is based on the functions of exclusion and usurpation. Depending on the individual, social groups attribute themselves within a wider context where, as in the case of individuals, an important role is played by the dominant ideology, which sets the framework not only of social interaction, but also of the functions and objectives of the social institutions, creating in proportion distorted collective class consciousnesses. In the 
recent years (and certainly before the current economic downturn), what was observed in Greece was a clear reallocation of labor, whose characteristics were, on the one hand, the accession of immigrants in occupations linked associatively and materialistically with the lower social classes and, on the other hand, the pressure of the indigenous labor force to be occupied in jobs that are connected, even imaginary, with the middle and higher social positions. In this way, they created the illusion of the upward social mobility for a large part of the indigenous population. This illusion drew its momentum from living manifestations and the semiotic symbolism without, generally, taking account of the material living conditions.

Studies have shown those men, the rich and better educated, are more political active, and are often involved in demonstrations and protests (Egmond et al., 1998; Kim et al., 1975; Leighley \& Nagler, 1992; Pattie \& Johnston, 1998). Hence, they are more prone to experience state violence. Moreover, social, psychological and demographic characteristics of society, are shown to be related to reaction and resistance (Verba et al., 1995), but also with the manner they perceive their class integration (Bassiou et al., 2).

Male and female students belong to a category which has three key features: (a) a higher level of education, compared to individuals of a comparable age, (b) a "benign" field of mingling, as the university is and (c ) a "positive" tradition toward protest and claim. Thus, this population is more likely to face state violence. However, it is natural that the views of this particular population towards state violence depend, on the one hand, on whether they participated in demonstrations and protests and, on the other hand, by the general political and social ideology that they adopt. It is ultimately a matter of political socialization (Sigel, 1995), the acquisition of which however - on the basis of the neoliberal practices and under the logic of which the state is subordinated today- becomes quite problematic, since the State itself is increasingly shrinking, is losing its political dimension and is transformed into a meta-power, keeping for itself only a role of policing, repression and surveillance for ordinary citizens, whereas it continues to offer social guarantees for the privileged ones (see. Gounaris in Macedo et al, 2010: 288-289).

\section{References}

Arendt, H. (2000). Regarding violence. Athens: Aleksandreia.

Bardin, L. (1977). L' analyse de contenu. Paris: PUF.

Bassiou, V., Kyridis, A., Zagkos, C., Nikos, P. (2012). Social classes vs professional stereotypes in Greece. A view to a traditional fogy social construction. Mediterranean Journal of Social Sciences, 3(3), 27 - 40.

Berelson, B. (1971). Content Analysis in Communication Research. New York: Hafner.

Besley, T., Persson, T. (2011). Pillars of Prosperity. Princeton University Press.

Boehnke, Klaus, Hagan, J John \& Merkens, Hans. 1998. Right-wing Extremism among 


\section{I Macrothink}

Journal of Sociological Research

ISSN 1948-5468

2016, Vol. 7, No. 2

German Adolescents: Risk Factors and Protective Factors. Applied Psychology: An International Review, 47:109-26.

Braud, Philippe. 1996. Sociologie politique. (3e edition). Paris: L.G.D.J.

Bryant, Jennings \& Oliver, Mary Beth. (Eds.) 2009. Media effects: Advances in theory and research. New York, NY: Routledge.

Charalambis, Dimitris. 1985. Military and Political Power - The structure of power in the post-civil war Greece. Athens: Exantas.

Coser, Lewis. 1956. The functions of social conflict. Glencoe: The Free press.

Curley, Kate. (1990). Content Analysis. In: E. Asher (Ed.), The Encyclopedia of Language and Linguistics. Edinburgh: Pergamon Press.

Curran, James. 2001. Public Media and dictatorship . Athens: Pataki.

Dagtoglou, PRODROMS. 1986. About domination. (Publication B', revised).Athens-Kommotini: Sakkoulas.

De Sola Pool Ithiel. 1959. Trends in Content Analysis. Urbana: University of Illinois Press.

Egmond, Marcel, De Graaf, Nan Dirk \& Van Der Eijk, Cees. 1998. Electoral participation in the Netherlands: Individual and contextual influences. European Journal of Political Research, 34, 281-300.

Evans, Peter. B. 1995. Embedded Autonomy. Princeton University Press.

Fromm, Erich. 1971. The fear towards freedom. Athens: Mpoukoumanis.

Gurr, Ted Robert. 1970. Why Men Rebel. Princeton: Princeton University Press.

Gurr, Ted Robert. 1976. Rogues, Rebels and Reformers: A Political History of Urban Crime and Conflict. Beverly Hills, Calif.: Sage Publications.

Goode, William J. 1972. Presidential Address: The Place of Force in Human Society. American Sociological Review, 37, 507 - 519.

Haidou, Anthozoi. 2003. Modern technology and social control. In: A., Haidou (Editor), Crime texts. Athens: Law Library.

Hancock, Gregory, R.. 2010. The reviewer's guide to quantitative methods in the social sciences. UK: Routledge.

Heitmeyer, Wilhelm \& Anhut, Reimund. 2008. Disintegration, Recognition and Violence: A Theoretical Perspective. New Directions for Youth Development, 119: 25-37.

Kim, Jae-on, Petrocik, John R. \& Enokson, Stephen N. 1975. Voter turnout among the American states: Systemic and individual components. American Political Science Review, 69, 107-131.

Kripppendorf, Klaus. 1980. Content Analysis: An introduction to its Methodology. London: 
Sage.

Kulish, Nicholas. 2011, September 27. As scorn for vote grows, protests surge around globe. The New York Times. Retrieved from http://www.nytimes.com/2011/09/28/world/as-scorn-for-vote-grows-protests-surge-around-gl obe.html

Kyriazi, Nota. 2001. The sociological research. Critical review of methods and techniques. (Series $C$ ). Athens: Greek Letters.

Kyridis, Argyris. 2014. Social vulnerability and social cohesion. In: A. Kyridis (Ed.), Vulnerable social Groups and Life Long Learning (21 - 65). Gutenberg: Athens.

Leighley, Jan E. \& Nagler, Jonathan. 1992. Individual and systemic influences on turnout: Who votes? Journal of Politics, 54, 718-740.

Leites, Nathan Constantin \& Wolf, Charles. 1970. Rebellion and Authority. An Analytic Essay on Insurgent Conflicts. Chicago: Markham.

Lenin, Vladimir. (2007). State and revolution. Athens: Modern era.

Macedo, Donaldo, Dendrinou, Vasiliki. \& Gounari, Panayota. 2010. The hegemony of English language. Thessaloniki: Epikentro.

Manitakis, Antonis \& Takis, Andreas. (2004). Terrorism and Rights. From the safety of the state to the legal uncertainty. Athens: Savalas.

Mavrias, Kostas. 2000. Theory of the State-Regime-state functions. Athens: Sakkoulas.

Michalopoulou, Rena. 1992. Scales of measuring attitudes. Athens: Odysseas.

Mill John Stuart. 1983. On Liberty. (translation: G. Balis). Athens: Epikouros

Mucchieli, Roger. 1988. L' analyse de contenu des documents et des communications. Paris: Les Editions ESF.

Munoz, Victoria. 1995. Where "something catches": Work, love, and identity in your youth. Albany, NY: State University of New York Press.

Parkin, Frank. 1971. Class Inequality and Political Order. London: McGibbon \& Kee.

Pattie, Charles \& Johnston, Ron. 1998. Voter turnout at the British general election of 1992: Rational choice, social standing or political efficacy? European Journal of Political Research, $33,268-283$.

Pauwels, Lieven \& De Waele, Maarten S. 2014. Youth Involvement in Politically Motivated Violence: Why Do Social Integration, Perceived Legitimacy, and Perceived Discrimination Matter? International Journal of Conflict and Violence, 8(1), 134 - 153.

Peirce, Bonny Norton. 1995. Social identity, investment, and language learning. TESOL Quarterly, 29(1), 9-31. 


\section{Macrothink}

Pihas, Kostas. 1997. The Police institution. In: Police Review, 35-67, 324 and 548-563.

Poulantzas, Nikos. 1975. Classes in Contemporary Capitalism. London: Verso.

Poulantzas, Nikos. 1985. Political power and social classes, Volume b, edition C, Athens: Themelio

Schmid, Alex P. \& Jongman, J. Albert. 1988. Political Terrorism: A New Guide to Actors, Authors, Concepts. Data Bases, Theories and Literature. U.S.A: Harvard University.

Sigel, Roberta. 1995. New directions for political socialization research. Perspectives in Political Science, 24(1), 17-22.

Simopoulos, Kyriakos. 1995. The corruption of authority. Athens: Self Edition.

Sproat, Peter. 1996. The Quantitative Results of a Questionnaire on State Terrorism. Terrorism and Political Violence, 8(3), p. 64-86.

Stergioulis, Evangelos. 1996. The social impact of the media. In: Police Inspection, pp.667-674.

Stohl, Michael, \& Lopez, George. 1984. The State as Terrorist. London: Aldwych.

Tsalikoglou, Fotini. 1996. Mythologies of violence and repression. Athens: Papazisi.

Tsiris, Panagiotis. 2002. The constitutional guarantee of the confidentiality of correspondence. Athens-Komotini: Sakkoulas

Verba, Sidney, Schlozman, Kay Lehman, \& Brady, Henry. 1995. Voice and equality: Civic voluntarism in American politics. Cambridge, MA: Harvard University Press.

Weber, Max. 1956. A study in political Sociology. London: Faber \& Faber

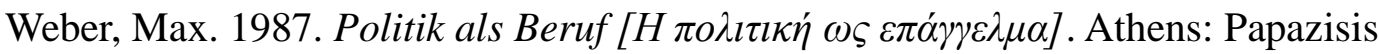

Weber Robert. 1990. Basic Content Analysis. Newbury Park: Sage.

Weil, Eric. 1971. Philosophie politique. Paris: Librairie Philosophique J. Vrin.

Wright, Erik Olin. 1978. Class, Crisis and the State. London: New Left Books.

Wright, Erik Olin. 1985. Classes. London: Verso.

Zuquete, Jose Pedro. (2011). Another world is possible? Utopia revisited. New Global Studies, 5(2), 1 - 19. doi: 10.2202/1940-0004.1130. 


\section{Macrothink}

Journal of Sociological Research

ISSN 1948-5468

2016, Vol. 7, No. 2

\section{Appendix}

\begin{tabular}{|c|c|c|c|}
\hline & Statements & Mean & $\mathrm{SD}$ \\
\hline 1 & State violence is the violence exercised by the police & 3.04 & 1.182 \\
\hline 2 & State violence is included in the violence imposed by the police & 3.48 & 1.152 \\
\hline 3 & State violence is also included in the symbolic violence & 3.67 & .978 \\
\hline 4 & State violence is the provocative actions of parties and parliamentarians & 4.00 & .901 \\
\hline 5 & State violence is the preventive, undue police control on the road & 3.12 & 1.263 \\
\hline 6 & State violence is changing and varies from country to country & 4.16 & .863 \\
\hline 7 & Configuration of the consciousness through television is state violence & 3.88 & 1.016 \\
\hline 8 & State violence is violence by the State to its citizens & 4.01 & .936 \\
\hline 9 & State violence is promoted by the privatization of education & 3.17 & 1.022 \\
\hline 10 & The State is entitled to exercise violence & 2.45 & 1.294 \\
\hline 11 & Without state violence the structure of the state is under threat & 2.30 & 1.175 \\
\hline 12 & The state violence is promoted through the system of cameras and surveillance & 3.80 & 1.048 \\
\hline 13 & State violence is the constant change of labor relations & 3.61 & 1.062 \\
\hline 14 & State violence is the continuous evaluation and monitoring of the performance of students through examinations & 2.65 & .995 \\
\hline 15 & State violence is the threat of state bankruptcy & 3.76 & 1.193 \\
\hline 16 & State violence is lawful & 2.21 & 1.326 \\
\hline 17 & State violence is the censorship in the media and on the internet & 3.71 & 1.162 \\
\hline 18 & State violence is a prerequisite in defense and legalization & 2.41 & 1.136 \\
\hline 19 & State violence is necessary to maintain the cohesion of the social fabric & 2.32 & 1.138 \\
\hline 20 & The state violence is necessary but excessive & 2.26 & 1.190 \\
\hline 21 & State violence can be exercised through the terror of the law & 3.04 & 1.290 \\
\hline 22 & The state violence is a necessary evil because through this the & 2.36 & 1.189 \\
\hline 23 & The army is an exercising body of state violence & 2.96 & 1.287 \\
\hline 24 & The state violence is the political mobilization against strikers & 3.36 & 1.151 \\
\hline 25 & The state violence is reinforced by the lack of the rule of law & 3.99 & 1.101 \\
\hline 26 & The state violence is the institutional fortification of the economic, military and political elites & 3.82 & 1.137 \\
\hline 27 & In the state violence, social peace is imposed & 2.10 & 1.124 \\
\hline 28 & The state violence is based on the concepts of "national interest" and "legality" & 3.16 & 1.244 \\
\hline 29 & The state violence is ever seen in atrocious working conditions, accommodation & 3.65 & 1.080 \\
\hline 30 & State violence is the continued increase in taxes and VAT & 3.99 & .964 \\
\hline
\end{tabular}




\section{Macrothink}

\section{Copyright Disclaimer}

Copyright for this article is retained by the author(s), with first publication rights granted to the journal.

This is an open-access article distributed under the terms and conditions of the Creative Commons Attribution license (http://creativecommons.org/licenses/by/3.0/). 